\title{
OUTCOMES OF SURGICAL TREATMENT OF OBESE PATIENTS WITH VENTRAL AND INCISIONAL HERNIAS
}

\author{
Volodymyr I. PIATNOCHKA ${ }^{\bowtie}$
}

Surgery Department, I.Y. Horbachevsky State Medical University, Ukraine

Received 15 Sept 2018, Accepted 14 Nov 2018

hitps://doi.org/10.31688/ABMU.2019.54.1.14

\section{Abstract}

Introduction. The results of the surgical treatment of ventral and incision hernias in the obese patients are poor, because of the high incidence of complications and relapses.

The objective of the study was to analyse the outcomes of patients with hernias, obesity and non-specific connective tissue dysplasia (NSCTD), and to define the main predictors of complications development.

Methods. We analysed the outcomes of treatment in 1133 patients, who underwent surgery for primary and incision ventral hernia between 2006-2017.

Results. Pulmonary embolism was diagnosed in $0.62 \%$ of the patients, abdominal compartment syndrome (ACS) in $3.0 \%$ of the individuals, after stretching hernioplasty. The highest incidence of wound complications was evidenced in patients with stage 3 obesity $-35.14 \%$. The signs of NSCTD were present in $53.45 \%$ of the patients with recurrent hernia, and in $18.61 \%$ of the patients with no recurrence of hernia. In patients with obesity stage 1 and 2, the development of ACS depended only on the chosen method of surgical intervention. In patients with no recurrent hernia, the division of patients according to their blood groups did not significantly differ from the general population.

\section{Résumé}

Résultats du traitement chirurgical des patients aux comorbidités présentant d' hernies ventrale et incisée

Introduction. Les résultats du traitement chirurgical des hernies ventrale et incisée chez les patients présentant une obésité morbide concomitante sont médiocres, comme en témoignent un grand nombre de complications et une incidence élevée de rechutes.

Objectifs et méthodes. Les résultats du traitement chirurgical de 1133 patients présentant une obésité morbide concomitante et une dysplasie du tissu conjonctif non spécifique, opérés pour une hernie ventrale primitive et incisée en 2006-2017, ont été analysés.

Résultats et discussion. Une embolie pulmonaire a été diagnostiquée chez 0,62\% des patients et un syndrome du compartiment abdominal chez 3\% des personnes ayant subi une hernioplastie par étirement. Chez les patients obèses, aux stades 1 et 2 , le développement du SCA dépend uniquement de la méthode d'intervention chirurgicale choisie. L'incidence la plus élevée de complications des plaies a été mise en évidence chez les patients souffrant d'obésité, stade 3 35,14\%. Les signes de NSCTD étaient présents chez $53,45 \%$ des patients présentant une hernie récidivante 
Conclusions. The non-stretching methods of hernioplasty should be a priority, especially for patients with morbid obesity, stage 2-3, and significant comorbidity. The risk group for relapses also includes the patients with NSCTD and A(2) blood group, since the incidence of NSCTD in these individuals is statistically significantly higher.

Keywords: ventral hernia, incision hernia, morbid obesity, non-specific connective tissue dysplasia, complications.

Abbreviations: $\mathrm{CF}$ - cardiac failure, $\mathrm{RF}$ - respiratory failure, NSCTD - non-specific connective tissue dysplasia, CST - components separation techniques, ACS - abdominal compartment syndrome, TAR transversus abdominis muscle release.

\section{INTRODUCTION}

Most patients with incision hernias suffer from concomitant morbid obesity and make a special risk group for the incidence of complications after surgical interventions $\mathrm{s}^{1.5}$. In Ukraine, obesity affects $28.5 \%$ of the general population, $48 \%$ being overweight ${ }^{6}$. The views of the most surgeons are different regarding the treatment of these patients. No individualized approach to each patient, without considering the probable factors of hernia development, comorbidities, lack of sufficient experience and skills in choosing the optimal surgery method, lead to poor results of treatment ${ }^{7-10}$. Despite a significant number of surgical methods for abdominal wall correction, the results of surgical treatment of ventral and incision hernias are unsatisfactory, as evidenced by a large number of complications and a high incidence of relapses $(4.5-42 \%)^{11-19}$.

The ObJective OF OUR STUDY was to analyse the results of the surgical treatment in patients with ventral and incision hernia, as well as to define the main predictors of complications in patients with morbid obesity.

\section{Material AND Methods}

The analysis of the results of surgical treatment in 1133 patients, who underwent surgery for primary and incision ventral hernia, with underlying concomitant morbid obesity in 2006-2017, was performed at the Surgery Clinic of Academic and Research Institute of et chez 18,61\% des sujets opérés sans récidive de hernie. Conclusions. Les méthodes de non-étirement de l'hernioplastie devraient être une priorité, en particulier pour les patients présentant une obésité morbide, un stade 2-3 et une comorbidité significative. Le groupe à risque pour les rechutes devrait également inclure les patients présentant un groupe sanguin NSCTD et un groupe sanguin $\mathrm{A}(2)$, puisque l'incidence de la NSTDCD chez ces personnes est statistiquement significativement plus élevée.

Mots-clés: hernie ventrale, hernie incisée, obésité morbide, dysplasie du tissu conjonctif non spécifique, complications.

Abréviations: $\mathrm{CF}$ - insuffisance cardiaque, RF - insuffisance respiratoire, NSCTD - dysplasie du tissu conjonctif non spécifique, techniques de séparation des composants CST, SCA - syndrome du compartiment abdominal, TAR - relâchement du muscle transversus abdominis.

Postgraduate Education of I. Horbachevsky Ternopil State Medical University, at the premises of Ternopil City Clinical Hospital No 2, Ukraine. 881 women (77.75\%) and 252 men (22.24\%) were involved in the study. The age of the patients was from 18 to 84 years old (the average age $53.4 \pm 5.6$ years old). The time of herniation was from 2 to 34 years. Primary ventral hernias were evidenced in 199 (17.56\%) patients. The other 934 (82.43\%) patients suffered from postoperative (incision) hernia.

\section{Results}

Among the examined 1133 patients with obesity, $461(40.68 \%)$ patients suffered from stage 1 obesity; $359(31.68 \%)$ stage 2 obesity, and 311 (27.44\%) stage 3 obesity. Except morbid obesity, no other somatic pathology was revealed in 232 (20.47\%) patients, who underwent surgery. Determination of the cardiac failure (CF) using NYHA classification revealed class I in $695(61.34 \%)$ patients, class II in 419 (36.98\%), and class III in $19(1.68 \%)$ individuals (Table 1).

$882(77.85 \%)$ patients with respiratory failure (RF) type I underwent surgery; 222 (19.59\%) - with RF type II; and 29 (2.56\%) - with RF type III, respectively. It should be noted that all patients with RF type III underwent urgent salvage surgery for complications of ventral and incision hernias. 402 (35.48\%) patients suffered from varicose disease of lower limbs and insufficiency of valvular apparatus of shin veins. Diabetes mellitus was diagnosed in 154 (13.6\%) patients, type 1 in 20 (1.77\%), and type 2 in 134 (11.83\%) individuals. Non-specific connective tissue dysplasia (NSCTD) 
Table 1. Comorbidities of obese patients with ventral hernias.

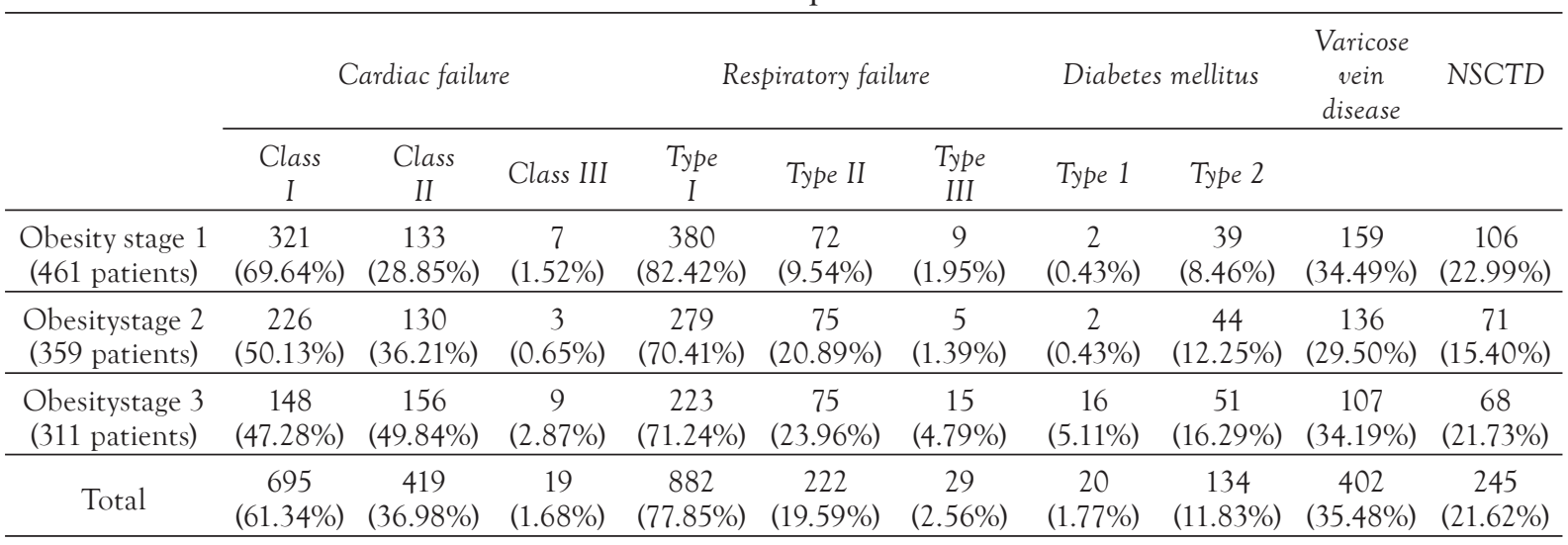

Table 2. Types of surgical interventions conducted for ventral hernias in the patients with obesity.

\begin{tabular}{|c|c|c|c|c|c|c|c|c|}
\hline & $\begin{array}{l}\text { Native tissue } \\
\text { hernioplasty }\end{array}$ & Onlay & Inlay & Sublay & CST & Dermatolipectomy & $\begin{array}{l}\text { Lightweight } \\
\text { mesh }\end{array}$ & $\begin{array}{c}\text { Heavyweight } \\
\text { mesh }\end{array}$ \\
\hline $\begin{array}{c}\text { Obesity, stage } 1 \\
\text { (461 patients) }\end{array}$ & $\begin{array}{c}149 \\
(32.32 \%) \\
\end{array}$ & $\begin{array}{c}156 \\
(33.84 \%) \\
\end{array}$ & $\begin{array}{c}21 \\
(4.56 \%) \\
\end{array}$ & $\begin{array}{c}132 \\
(28.63 \%) \\
\end{array}$ & $\begin{array}{c}8 \\
(1.74 \%) \\
\end{array}$ & $\begin{array}{c}12 \\
(2.60 \%) \\
\end{array}$ & $\begin{array}{c}126 \\
(27.33 \%) \\
\end{array}$ & $\begin{array}{c}173 \\
(37.53 \%) \\
\end{array}$ \\
\hline $\begin{array}{l}\text { Obesity, stage } 2 \\
\text { (359 patients) }\end{array}$ & $\begin{array}{c}103 \\
(22.34 \%) \\
\end{array}$ & $\begin{array}{c}118 \\
(25.60 \%) \\
\end{array}$ & $\begin{array}{c}27 \\
(5.86 \%) \\
\end{array}$ & $\begin{array}{c}110 \\
(23.86 \%) \\
\end{array}$ & $\begin{array}{c}11 \\
(2.38 \%) \\
\end{array}$ & $\begin{array}{c}83 \\
(18.00 \%) \\
\end{array}$ & $\begin{array}{c}114 \\
(24.73 \%) \\
\end{array}$ & $\begin{array}{c}122 \\
(36.46 \%) \\
\end{array}$ \\
\hline $\begin{array}{c}\text { Obesity, stage } 3 \\
\text { (311 patients) }\end{array}$ & $80(25.56 \%)$ & $\begin{array}{c}127 \\
(40.58 \%) \\
\end{array}$ & $\begin{array}{c}29 \\
(9.27 \%) \\
\end{array}$ & $\begin{array}{c}64 \\
(20.45 \%) \\
\end{array}$ & $\begin{array}{c}14 \\
(4.48 \%) \\
\end{array}$ & $\begin{array}{c}177 \\
(56.55 \%) \\
\end{array}$ & $96(30.67 \%)$ & $\begin{array}{c}130 \\
(41.53 \%) \\
\end{array}$ \\
\hline Total & $\begin{array}{c}332 \\
(29.30 \%) \\
\end{array}$ & $\begin{array}{c}401 \\
(35.39 \%)\end{array}$ & $\begin{array}{c}77 \\
(6.80 \%) \\
\end{array}$ & $\begin{array}{c}306 \\
(27.01 \%)\end{array}$ & $\begin{array}{c}33 \\
(2.91 \%)\end{array}$ & $\begin{array}{c}272 \\
(24.01 \%)\end{array}$ & $\begin{array}{c}336 \\
(29.66 \%)\end{array}$ & $\begin{array}{c}425 \\
(37.51 \%)\end{array}$ \\
\hline
\end{tabular}

Table 3. Complications of surgical treatment of ventral hernias in patients with obesity.

\begin{tabular}{|c|c|c|c|c|c|c|c|c|c|}
\hline & \multirow{2}{*}{$\begin{array}{c}\text { Frequency of } \\
\text { postoperative } \\
\text { complica- } \\
\text { tions }\end{array}$} & \multirow[b]{2}{*}{$P E$} & \multirow[b]{2}{*}{ ACS } & \multirow[b]{2}{*}{ Exacerbation } & \multicolumn{5}{|c|}{ Wound complications } \\
\hline & & & & & $\begin{array}{c}\text { Prolonged } \\
\text { lymphor- } \\
\text { rhoea }\end{array}$ & $\begin{array}{l}\text { Infiltrate of } \\
\text { postopera- } \\
\text { tive wound }\end{array}$ & $\begin{array}{c}\text { Postoperative } \\
\text { wound } \\
\text { abscess }\end{array}$ & $\begin{array}{l}\text { Cysts of } \\
\text { the mesh } \\
\text { region }\end{array}$ & Rejection \\
\hline $\begin{array}{l}\text { Obesity stage } 1 \\
\text { (461 patients) }\end{array}$ & $\begin{array}{c}149 \\
(32.32 \%)\end{array}$ & $\begin{array}{c}4 \\
(0.87 \%) \\
\end{array}$ & $\begin{array}{c}6 \\
(1.30 \%)\end{array}$ & $\begin{array}{c}58 \\
(12.58 \%) \\
\end{array}$ & $\begin{array}{c}100 \\
(21.69 \%)\end{array}$ & $\begin{array}{c}117 \\
(25.38 \%)\end{array}$ & $28(6.07 \%)$ & $\begin{array}{c}34 \\
(7.38 \%)\end{array}$ & $\begin{array}{c}6 \\
(1.30 \%)\end{array}$ \\
\hline $\begin{array}{c}\text { Obesity stage } 2 \\
\text { (359 patients) }\end{array}$ & $\begin{array}{c}171 \\
(37.09 \%)\end{array}$ & $\begin{array}{c}1 \\
(0.22 \%) \\
\end{array}$ & $\begin{array}{c}7 \\
(1.52 \%) \\
\end{array}$ & $\begin{array}{c}43 \\
(9.33 \%) \\
\end{array}$ & $\begin{array}{c}129 \\
(27.98 \%) \\
\end{array}$ & $\begin{array}{c}144 \\
(31.24 \%)\end{array}$ & $45(9.76 \%)$ & $\begin{array}{c}39 \\
(8.46 \%) \\
\end{array}$ & $8(1.74 \%)$ \\
\hline $\begin{array}{c}\text { Obesity stage } 3 \\
\text { (311 patients) }\end{array}$ & $\begin{array}{c}146 \\
(46.65 \%) \\
\end{array}$ & $\begin{array}{c}2 \\
(0.64 \%) \\
\end{array}$ & $\begin{array}{c}21 \\
(6.71 \%) \\
\end{array}$ & $\begin{array}{c}37 \\
(11.82 \%) \\
\end{array}$ & $\begin{array}{c}102 \\
(32.59 \%)\end{array}$ & $\begin{array}{c}110 \\
(35.14 \%)\end{array}$ & 37 (11.82\%) & $\begin{array}{c}28 \\
(8.95 \%) \\
\end{array}$ & $\begin{array}{c}9 \\
(2.88 \%) \\
\end{array}$ \\
\hline Total & $\begin{array}{c}466 \\
(41.13 \%)\end{array}$ & $\begin{array}{c}7 \\
(0.62 \%)\end{array}$ & $\begin{array}{c}34 \\
(3.00 \%)\end{array}$ & $\begin{array}{c}138 \\
(12.18 \%)\end{array}$ & $\begin{array}{c}331 \\
(29.21 \%)\end{array}$ & $\begin{array}{c}371 \\
(32.74 \%)\end{array}$ & $\begin{array}{c}110 \\
(9.71 \%)\end{array}$ & $\begin{array}{c}101 \\
(8.91 \%)\end{array}$ & $\begin{array}{c}23 \\
(41.13 \%)\end{array}$ \\
\hline
\end{tabular}

(5 and more phenotypic signs) was diagnosed in 245 (21.62\%) of the examined patients. A higher frequency of CF class II, RF type I, and diabetes mellitus type 2 in the patients with stage 3 obesity was evidenced, compared to the patients with obesity stage 1 .

332 (29.30\%) patients underwent native tissue hernioplasty. Prosthetic plasty was performed in most patients (704, 62.13\%) who underwent surgery, among them On-lay for 401 (35.39\%), and Sub-lay for 306 (27.00\%) individuals, respectively. The components separation techniques (CST) of hernioplasty were carried out only for $33(2.91 \%)$ patients with giant incisive hernias; no primary hernias were present in this group of patients (Table 2).

Pulmonary embolism (PE) was diagnosed in 7 (0.62\%) patients who underwent surgery: 4 patients suffering from $1^{\text {st }}$ stage obesity, 1 patient with obesity stage 2 , and 2 with obesity stage 3 (Table 3 ). In all cases with PE, the stretching forms of hernioplasty were conducted: native tissue hernioplasty in 2 patients and in 5 cases in allogernioplasty by On-lay method. As a comparison, in patients without morbid obesity (256 patients, who underwent surgery), pulmonary embolism was not evidenced in the postoperative period. 
Table 4. Frequency of NSCTD in patients with ventral and incisional hernia in cases of morbid obesity.

\begin{tabular}{|c|c|c|}
\hline Stage of Obesity & The postoperative outcomes & Frequency of NSCTD \\
\hline \multirow{2}{*}{$\begin{array}{l}\text { Obesity, stage } 1 \\
\text { (461 patients) }\end{array}$} & $\begin{array}{c}\text { No relapses } \\
n=403\end{array}$ & $\begin{array}{c}75 \\
(18.61 \%) \\
\end{array}$ \\
\hline & $\begin{array}{l}\text { Presence of relapses } \\
\qquad \mathrm{n}=58\end{array}$ & $\begin{array}{c}31 \\
(53.45 \%)\end{array}$ \\
\hline \multirow{2}{*}{$\begin{array}{l}\text { Obesity, stage } 2 \\
\text { (359 patients) }\end{array}$} & $\begin{array}{c}\begin{array}{c}\text { No relapses } \\
\mathrm{n}=316\end{array} \\
\end{array}$ & $\begin{array}{c}52 \\
(16.46 \%) \\
\end{array}$ \\
\hline & $\begin{array}{l}\text { Presence of relapses } \\
n=43\end{array}$ & $\begin{array}{c}19 \\
(44.19 \%) \\
\end{array}$ \\
\hline \multirow{2}{*}{$\begin{array}{l}\text { Obesity, stage } 3 \\
\text { (313 patients) }\end{array}$} & No relapses $n=276$ & $\begin{array}{c}47 \\
(17.03 \%) \\
\end{array}$ \\
\hline & $\begin{array}{l}\text { Presence of relapses } \\
n=37\end{array}$ & $\begin{array}{c}21 \\
(56.76 \%)\end{array}$ \\
\hline \multicolumn{2}{|c|}{ Total } & $245(21.64 \%)$ \\
\hline
\end{tabular}

\section{Discussion}

A significantly higher frequency of wound complications was evidenced in patients with obesity stage 3. In our opinion, this is due to more frequent dermatolipectomy in this group of patients.

Abdominal compartment syndrome (ACS) was diagnosed in 34 patients, who underwent surgery: 6 patients with obesity stage 1,7 patients with obesity stage 2 , and 21 patients with obesity stage 3. Stretching hernioplasty was conducted in 30 cases (by native tissue -9 , on lay method -21 ). Non-stretching allogernioplasty was performed for 4 patients (sub lay - 1, TAR (transversus abdominis muscle release) - 3). In addition, ACS after the stretching allogernioplasty was present in 6 patients with obesity stage 1 , in 6 patients with obesity stage 2 , and in 18 individuals with obesity stage 3 . In the group of patients who underwent surgery by non-stretching methods of allogernioplasty, ACS was evidenced in 1 patient with obesity stage 2 , and in 3 individuals with obesity stage 3 . In cases of obesity absence, $4(1.55 \%)$ patients who underwent surgery suffered from ACS. Thus, in patients with obesity stage 1 and 2, ACS depended only on the method of surgical intervention chosen. A significantly higher frequency of ACS in patients with obesity stage 3 proved that the method of surgical correction of anterior abdominal wall, as well as the changes (oedema) of adipose tissue of abdominal cavity of retroperitoneal space, paresis of intestine in the early postoperative period, are crucial in the development of this complication. This requires expansion of surgical intervention - omentectomy, and right hemicolectomy in rare cases.

In $245(21.64 \%)$ patients with concomitant morbid obesity, who underwent surgery, the presence of phenotypic signs of non-specific connective tissue dysplasia was confirmed. 461 patients with obesity stage 1 underwent surgery; among them, the relapse of hernia was evidenced in 58 patients. Moreover, in patients with recurrent hernia, the signs of NSCTD were present in 31 (53.45\%) individuals, and in 75 $(18.61 \%)$ patients with no recurrent hernia, who underwent surgery. Obesity stage 2 was diagnosed in 359 patients who underwent surgery, among them the recurrence of hernia was evidenced in 43 individuals (Table 4).

The frequency of NSCTD without relapse was determined in $52(16.46 \%)$ patients and with its recurrence in 19 (44.19\%) individuals. Similar changes were evidenced in patients with obesity, stage 3 - 313 individuals. Among them, the frequency of NSCTD in patients without recurrent hernia was determined in $47(17.03 \%)$ patients, and in cases of its recurrence in $21(56.76 \%)$ individuals.

The analysis of phenotypic features of non-specific connective tissue dysplasia in patients with incision hernia and concomitant morbid obesity who underwent surgery was carried out. Thus, it was proved that in the patients with blood group A (2) NSCTD was present in $236(33.57 \%)$ cases and was of the highest incidence compared to the patients with $\mathrm{O}$ (1), B (3) and AB (4) blood groups in 67 (18.72\%), 52 (18.91\%) and 20 (24.10\%) individuals, respectively (Table 5).

Among the patients with recurrent hernia, blood group $\mathrm{A}(2)$ was in $38(62.52 \%)$ patients with obesity stage 1 , in $29(67.45 \%)$ with obesity stage 2 , and in 20 (54.05\%) individuals with obesity stage 3 (Table 6).

In patients with no recurrent hernia, the division of patients according to their blood groups did not significantly differ from the general population. Thus, the patients with blood group A (2) are a risk group for recurrence of hernia, probably due to a significantly higher frequency of NSCTD. 
Table 5. Frequency of NSCTD in 1133 examined patients, depending on the blood group

\begin{tabular}{cc}
\hline Blood group & Frequency of NSCTD \\
\hline O(1) & $\mathrm{n}=67$ \\
$=286(25.22 \%)$ & $18.72 \%$ \\
\hline $\mathrm{A}(2)$ & $\mathrm{n}=236$ \\
$=562(49.54 \%)$ & $33.57 \%$ \\
\hline $\mathrm{B}(3)$ & $\mathrm{n}=52$ \\
\hline $\mathrm{n}=219(19.37 \%)$ & $18.91 \%$ \\
\hline $\mathrm{AB}(4)$ & $\mathrm{n}=20$ \\
\hline
\end{tabular}

Table 6. Incidence of NSCTD in the patients with ventral and incisional hernia in cases of morbid obesity, depending on blood group.

\begin{tabular}{|c|c|c|c|c|c|}
\hline \multicolumn{2}{|c|}{ Blood group } & $\mathrm{O}(1)$ & $A(2)$ & $B(3)$ & $A B(4)$ \\
\hline \multirow{2}{*}{$\begin{array}{l}\text { Obesity, stage } 1 \\
\text { (461 patients) }\end{array}$} & $\begin{array}{c}\text { No relapses } \\
n=403\end{array}$ & $116(28.78 \%)$ & $\begin{array}{c}158 \\
(39.2 \%)\end{array}$ & $\begin{array}{c}96 \\
(23.83 \%)\end{array}$ & $\begin{array}{c}33 \\
(8.19 \%) \\
\end{array}$ \\
\hline & $\begin{array}{l}\text { Presence of relapses } \\
n=58\end{array}$ & $\begin{array}{c}16 \\
(27.58 \%)\end{array}$ & $\begin{array}{c}38 \\
(62.52 \%)\end{array}$ & $\begin{array}{c}4 \\
(6.9 \%)\end{array}$ & $\begin{array}{c}0 \\
(0.00 \%)\end{array}$ \\
\hline \multirow{2}{*}{ Obesity, stage 2 (359 patients) } & $\begin{array}{c}\text { No relapses } \\
\mathrm{n}=316 \\
\end{array}$ & $\begin{array}{c}74 \\
(23.42 \%) \\
\end{array}$ & $\begin{array}{c}157 \\
(49.69 \%) \\
\end{array}$ & $\begin{array}{c}60 \\
(18.99 \%) \\
\end{array}$ & $\begin{array}{c}25 \\
(7.91 \%) \\
\end{array}$ \\
\hline & $\begin{array}{l}\begin{array}{l}\text { Presence of relapses } \\
n=43\end{array} \\
\end{array}$ & $\begin{array}{c}11 \\
(25.59 \%) \\
\end{array}$ & $\begin{array}{c}29 \\
(67.45 \%) \\
\end{array}$ & $\begin{array}{c}2 \\
(4.66 \%) \\
\end{array}$ & $\begin{array}{c}1 \\
(2.33 \%)\end{array}$ \\
\hline \multirow{2}{*}{ Obesity, stage 3 (313 patients) } & $\begin{array}{c}\text { No relapses } \\
n=276\end{array}$ & $\begin{array}{c}53 \\
(19.2 \%)\end{array}$ & $\begin{array}{c}167 \\
(60.5 \%)\end{array}$ & $\begin{array}{c}44 \\
(15.94 \%)\end{array}$ & $\begin{array}{c}12 \\
(4.35 \%)\end{array}$ \\
\hline & $\begin{array}{l}\text { Presence of relapses } \\
n=37\end{array}$ & $\begin{array}{c}13 \\
(35.14 \%)\end{array}$ & $\begin{array}{c}20 \\
(54.05 \%)\end{array}$ & $\begin{array}{c}2 \\
(5.4 \%)\end{array}$ & $\begin{array}{c}2 \\
(5.4 \%)\end{array}$ \\
\hline
\end{tabular}

\section{Conclusions}

The non-stretching methods of hernioplasty should be a priority, especially in the groups of patients with morbid obesity, stage 2-3, and significant comorbidities, that allow reducing the number of early postoperative complications and relapses significantly.

The dermatolipectomy significantly increases the incidence of wound complications in patients with ventral and incision hernia and morbid obesity, who require development of a stepwise approach of surgical treatment.

The frequency of abdominal compartment syndrome in patients with obesity stage 1 and 2 does not differ from the frequency of this complication in non-obese patients. The development of abdominal compartment syndrome depends only on the method of surgical intervention chosen.

In patients with obesity stage 3, a significantly higher incidence of abdominal compartment syndrome is evidenced, that requires expansion of surgical intervention - omentectomy, and right hemicolectomy in rare cases.

The incidence of relapse after surgical interventions in patients with ventral and incision hernia and morbid obesity depends on the type of surgical intervention, as well as on the presence of non-specific connective tissue dysplasia, which has been evidenced in $53.45 \%$ of patients who underwent surgery, with obesity stage 1 ; in $44.19 \%$ with obesity stage 2 ; and in $56.76 \%$ of individuals with obesity stage 3 .

Besides the phenotypic signs and biochemical markers of non-specific connective tissue dysplasia, the risk factors of relapse are also A (2) blood group, since these patients have a statistically significantly higher frequency of NSCTD. The presence of the above-mentioned risk factors of incision hernia relapse, in patients with morbid obesity, requires the development of new methods of surgical treatment for these patients, as well as improvement of the existing ones.

\section{Compliance with Ethics Requirements:}

„The authors declare no conflict of interest regarding this article"

"The authors declare that all the procedures and experiments of this study respect the ethical standards in the Helsinki Declaration of 1975, as revised in 2008(5), as well as the national law. Informed consent was obtained from all the patients included in the study"

„No funding for this study" 


\section{References}

1. Ganzhyi VV. Surgical treatment of postoperative ventral hernias with one-time abdominoplasty and liposuction. Surgery of Ukraine 2011;3(39) (Suppl):26-28.

2. Lavryk AS. Current approaches to surgical treatment of anterior abdominal wall hernia in the patients with obesity. Current methods and technologies in surgical treatment of abdominal hernias: Materials of the 9th International Research and Training Conference. Koblevo, 2016; P. 73-74.

3. Roje Z, Roje Z̆, Karanović N, Utrobičić I. Abdominoplasty complications: a comprehensive approach for the treatment of chronic seroma with pseudo bursa. Aesthetic Plastic Surgery 2006;30(5):611-615.

4. Herbala OYu. Actual problems of treatment of postoperative hernia in patients with obesity. Klinicheskaia khirurgiia 2010;3:45-49.

5. Autlo KM, Yanin AL, Kruchinina EV, Ivanov VV. Treatment of giant postoperative ventral hernias in patients with morbid obesity: Materials of the 5th Russian Symposium. Samara, 2009; P. 20

6. Lavryk AS, Tivonchuk OS, Lavryk OA. Surgical treatment of obesity. Zdorovia Ukrainy 2013;1:10-11.

7. Feleshtynskyi YaP, Dubenets VO, Vatamaniuk VF. Reparative-restorative tension free allogernioplasty in cases of giant postoperative hernias of abdomen. Surgery of Ukraine 2008;(4):65-68

8. Krpata DM, Blatnik JA, Novitsky YW, Rosen MJ. Evaluation of high-risk, comorbid patients undergoing open ventral hernia repair with synthetic mesh. Surgery 2013;153(1):120-125.

9. Breuing K, Butler CE, Ferzoco S, et al. Ventral Hernia Working Group. Incisional ventral hernias: review of the literature and recommendations regarding the grading and technique of repair. Surgery 2010;148(3):544-58.

10. Burger JW, Luijendijk RW, Hop WC, Halm JA, Verdaasdonk EG, Jeekel J. Long-term follow-up of a randomized controlled trial of suture versus mesh repair of incisional hernia. Annals of Surgery 2004;240(4):578-583.

11. Feleshtynskyi YaP, Mamchych VI, Vatamaniuk VF, Pylypenko TYu. Allogernioplasty of postoperative ventral hernias of giant sizes. Surgery of Ukraine 2008;4:280-1.

12. Socea B, Nica AA, Smaranda CA, et al. Solitary cecum diverticulitis - a surprising diagnosis. Arch Balk Med Union 2017;52(4):467-470.

13. Dziubanovskyi IYa, Piatnochka VI. Early complications after allogernioplasty of postoperative hernia of abdominal wall. Clinical Surgery. 2009;(11/12):33-4.

14. Woeste G, Juratli MA, Habbe N, et al. Abdominal wall hernia-abdominal wall closure. Hernia 2015;19:S198.

15. Rao RS, Gentileschi P, Kini SU. Management of ventral hernias in bariatric surgery. Surgery for Obesity and Related Diseases 2011;7(1):110-116.

16. Santora TA, Roslyn JJ. Incisional hernia. Surg Clin N Am 1993;73(3):557-70.

17. Hurwitz ZM, O'Brien J, Dunn RM. Pearls and pitfalls of an abdominal wall anatomy in component separation. Hernia 2011; 15(2):3.

18. Socea B, Nica AA, Bratu O, et al. Incidental finding of a sigmoid intussusception associated with rectal prolapse - a case report. Arch Balk Med Union 2018;53(1):143-146.

19. Kingsnorth AN. Hernia surgery: from guidelines to clinical practice. The Annals of The Royal College of Surgeons of England 2009;(91)4:273-279. 